\title{
ANALISIS SEMIOTIKA ROLAND BARTHES PADA PALANTAR NYANGAHATNMANTA' UPACARA NABO' PANTAK SUKU DAYAK KANAYATN
}

\author{
Ursula Dwi Oktaviani,Evi Fitrianingrum \\ STKIP Persada Khatulistiwa \\ ursuladwioktaviani@yahoo.com, fitrianingrumevi250@gmail.com
}

DOI: http://dx.doi.org/10.32528/bb.v4i2.2564

Diterbitkan: 30 Oktober 2019

\begin{abstract}
ABSTRAK
Upacara Nabo' Pantak merupakan upacara bersyukur dan meminta, pada masyarakat Dayak Kanayatn. Dayak Kanayatn mengenal tradisi bersyukur dan meminta dengan sebutan nyangahatn yang berupa mantra, nyangahatn dituturkan oleh panyangahatn (penutur mantra). Seperti halnya pada setiap upacara adat Dayak Kanayatn tidak terlepas dari nyangahatn , jadi pada upacara nabo' pantak ini juga demikian, tidak terlepas dari nyangahatn. Nyangahatn pada upacara nabo' pantak terbagi atas dua sesi yakni nyangahatn manta' dan nyangahatn masak, nyangahatn manta' merupakan nyangahatn yang dilakukan pada awal upacara nabo' pantak, sedangkan nyangahatn masak merupakan nyangahatn yang dilakukan pada akhir upacara nabo' pantak.Selain nyangahatn upacara nabo'pantak juga harus dilengkapi dengan perlengkapanperlengkapan upacara yang diadakan oleh masyarakat Dayak Kanayatn sebut palantar (sesajen). Penelitian ini bertujuan untuk mengungkap makna tanda-tanda pada palantar nyangahatn manta' upacara nabo' pantak suku Dayak Kanayatn di Dusun Pakbuis Desa Banying Kecamatan Sengah Temila Kabupaten Landak Provinsi Kalimantan Barat dari sudut pandang semiotika Roland Barthes.Dalam hal ini tanda-tanda dianalisis melalui penanda (signifier), petanda (signified), tanda denotatif (denotative sign), penanda konotatif (connotative signifier), petanda konotatif (connotative signified), dan tanda konotatif (connotative sign). Metode pada penelitian ini adalah kualitatif. Adapun hasil dari analisis palantar nyangahatn manta' pada upacara nabo' pantak ditemukan beberapa makna yakni makna konotatif, makna denotative, dan mitos.

Kata Kunci: Semiotika Roland Barthes, palantar nyangahatn manta'.
\end{abstract}

\section{ABSTRACT}

Nabo 'Pantak ceremony is a ceremony of giving thanks and requests something done by Dayak Kanayatn community. Dayak Kanayatn called the tradition of thanking and requesting as a nyangahatn in the form of a mantra or spell, nyangahatn is spelled by a panyangahatn (a mantra speaker). As in every traditional ceremony of Dayak Kanayatn, nyangahatn is a prerequisite. Therefore, in Nabo 'Pantak ceremony, nyangahatn is also obliged. Nyangahatn in Nabo' Pantak ceremony is divided into two sessions namely nyangahatn manta' and nyangahatn masak, nyangahatn manta' is nyangahatn which is done at the beginning of the Nabo Pantak ceremony, whereas nyangahatn masak is a nyangahatn which is done at the end of Nabo' Pantak ceremony. In addition, the nyabahatn Nabo'Pantak ceremony must also be completed with the ceremonial equipments required in the other ceremonies of Dayak Kanayatn people called as palantar (offerings). This study aims to uncover the meaning of signs in palantar nyangahatn manta in 'Nabo 'Pantak ceremony' done by Dayak Kanayatn tribe in Pakbuis Hamlet, Banying Village, Sengah Temila District, Landak Regency, West Kalimantan Province from the perspective of Roland Barthes semiotics. In this case the signs were analyzed through 
markers (signifier), signified, denotative sign, connotative signifier, connotative signified, and connotative sign. This study used qualitative method. The results of the analysis of palantar nyangahatn manta 'at the Nabo 'Pantak ceremony' found several meanings namely connotative meaning, denotative meaning, and myth.

Keywords: Roland Barthes Semiotics, palantar nyangahatn manta'

\section{PENDAHULUAN}

Nabo' Pantak terdiri dari dua kata yakni nabo' dan pantak, nabo' dalam bahasa Indonesia yang berarti kunjung: datang untuk menjumpai; bertandang; berziarah (KEMENDIKBUD, 2016). Sedangkan pantak dalam bahasa Indonesia yang berarti patung: tiruan bentuk orang, hewan, dan sebagainya dibuat (dipahat dan sebagainya) dari batu, kayu, dan sebagainya; arca (KEMENDIKBUD, 2016). Jadi nabo' pantak bisa diartikan sebagai berziarah atau datang pada patung. Bagi Dayak Kanayatn, upacara nabo' pantak bukanlah sekedar berziarah pada patung saja, melainkan bersyukur dan meminta berkat kepada Roh Leluhur untuk semua yang telah di terima maupun yang akan diminta.

Upacara nabo' pantak bisa dilakukan untuk semua upacara adat khususnya upacara Dayak Kanayatn dalam arti upacara adat yang berisi ucapan syukur, terima kasih dan permohonan. Upacara nabo' pantak merupakan upacara yang bersifat umum, karena bisa dilaksanakan kapan saja pada waktu yang sudah ditentukan dan dipilih. Selain bisa dilaksanakan kapan saja, upacara nabo' pantak juga bisa untuk meminta berbagai permintaan. Upacara nabo' pantak merupakan upacara bersyukur dan meminta, masyarakat Dayak Kanayatn mengenal tradisi bersyukur dan meminta dengan sebutan nyangahatn yang berupa mantra, nyangahatn dituturkan oleh panyangahatn (penutur mantra). Seperti halnya pada setiap upacara adat Dayak Kanayatn tidak terlepas dari nyangahatn, jadi pada upacara nabo' pantak ini juga demikian, tidak terlepas dari nyangahatn. Nyangahatn pada upacara nabo' pantak terbagi atas dua sesi yakni nyangahatn manta' dan nyangahatn masak, nyangahatn manta' merupakan nyangahatn yang dilakukan pada awal upacara nabo' pantak, sedangkan nyangahatn masak merupakan nyangahatn yang dilakukan pada akhir upacara nabo' pantak.

Selain nyangahatn, upacara nabo'pantak juga harus melengkapi perlengkapan-perlengkapan upacara yang biasa masyarakat Dayak Kanayatn sebut palantar (sesajen), isi palantar harus lengkap dan sesuai. Upacara nabo' pantak pada penelitian ini berada di Dusun Pakbuis Desa Banying
Kecamatan Sengah Temila Kabupaten Landak Provinsi Kalimantan Barat.

Penelitian upacara nabo' pantak menggunakan kajian semiotika Roland Barthes. Dalam hal ini tanda-tanda dianalisis melalui penanda (signifier), petanda (signified), tanda denotative (denotative sign), penanda konotatif (connotative signifier), petanda konotatif (connotative signified), dan tanda konotatif (connotative sign).

Semiotika adalah ilmu yang mempelajari tentang tanda yang mana tanda-tanda tersebut mewakili suatu pesan atau informasi yang bersifat komunikatif. Keberadaannya mampu menggantikan sesuatu yang lain, dapat dipikirkan atau dibayangkan. Cabang ilmu ini semula berkembang dalam bidang bahasa, kemudian berkembang pula dalam bidang desain dan seni rupa. Semiotika sebagai studi tentang tanda dan segala sesuatu yang berkaitan dengannya seperti cara berfungsinya, hubungannya dengan tanda-tanda lain, pengirimannya, dan penerimaannya oleh mereka yang mempergunakannya (Zoest, 1993). Ada pula yang mengatakan semiotika sebagai ilmu yang secara sistematik mempelajari tanda-tanda dan lambang-lambang, dan proses perlambangan (Pradopo, 2007). Dengan demikian semiotika juga bertautan dengan proses-proses 'signifikansi' (penandaan) dan dengan proses-proses 'komunikasi', yakni sebuah alat atau media tempat makna-makna ditetapkan dan dipertukarkan.

Sebagai sebuah disiplin keilmuan, yaitu ilmu tentang tanda (the science of sign), semiotika mempunyai prinsip, sistem, aturan, dan prosedurprosedur keilmuan yang khusus dan baku.

Semiotika bukanlah ilmu yang mempunyai sifat kepastian, ketunggalan, dan objektivitas, melainkan dibangun oleh pengetahuan yang lebih terbuka bagi aneka interpretasi(Tinarbuko, 2009).

Semiotika secara etimologi berasal dari bahasa Yunani (semion) yang berarti "tanda". Secara etimologi semiotika dapat didefinisikan sebagai ilmu tentang tanda-tanda. Ilmu ini menganggap bahwa fenomena sosial atau masyarakat dan kebudayaan itu merupakan bentuk dari tanda-tanda. Semiotik juga mempelajari sistem-sistem, aturan-aturan, konvensi-konvensi, yang memungkinkan tanda-tanda tersebut memiliki 
arti. Tanda-tanda atau (sign) adalah basis dari seluruh komunikasi. Manusia dengan perantaraan tanda-tanda dapat melakukan komunikasi dengan sesamanya (Sobur, 2016).

Salah seorang ahli teori kunci semiotika, Roland Barthes, mengembangkan gagasan gagasan Saussure dan mencoba menerapakan kajian tandatanda secara lebih luas lagi (1967). Melalui sebuah karier yang produktif dan menggairahkan dalam banyak fase budaya, Barthes memasukkan fesyen (1990), fotografi (1984) sastra (1987), majalah, dan musik diantara sekian banyak minatnya $(1973 ; 1984)$. Salah satu keasyikan utamanya adalah "bagaimana makna masuk kedalam citra/image" (Barthes, 2010). Dengan demikian dasar atau kunci dari semiotika adalah tentang bagaimana pencipta sebuah citra/image membuatnya bermakna, dan bagaimana pemahaman seseorang sebagai pembaca untuk mendapatkan maknanya.

\begin{tabular}{|c|c|c|c|}
\hline 1. & $\begin{array}{l}\text { Signifier } \\
\text { (penanda) }\end{array}$ & $\begin{array}{ll}\text { 2. } & \text { Signified } \\
\text { (petanda) }\end{array}$ & \\
\hline 3. & \multicolumn{2}{|c|}{$\begin{array}{l}\text { Denotative sign (tanda } \\
\text { denotatif) }\end{array}$} & \\
\hline \multirow[t]{2}{*}{4.} & \multicolumn{2}{|c|}{$\begin{array}{l}\text { CONNOTATIVE SIGNIFIER } \\
\text { (PENANDA } \\
\text { KONOTATIF) }\end{array}$} & $\begin{array}{l}\text { 5. } \text { CONNOTATIVE } \\
\text { SIGNIFIED(PETA } \\
\text { NDA } \\
\text { KONOTATIF) }\end{array}$ \\
\hline & 6. & JNOTATIVE SIGN & ANDA KONOTATIF) \\
\hline
\end{tabular}
2016)

Tabel. Peta tanda Roland Barthes. Sumber:(Sobur

Dari peta Barthes di atas terlihat bahwa tanda denotatif (3) terdiri atas penanda (1) dan petanda (2). Akan tetapi, pada saat bersamaan, tanda denotative adalah juga penanda konotatif (4). Dengan kata lain, hal tersebut merupakan unsur material: hanya jika anda mengenal tanda "singa", barulah konotasi seperti harga diri, kegarangan, keberanian menjadi mungkin Cobley dan Jansz dalam (Sobur, 2016). Jadi dalam konsep Barthes, tanda konotatif tidak sekedar memiliki makna tambahan namun juga mengandung kedua bagian tanda denotatif yang melandasi keberadaannya (Sobur, 2016).

Semiotika Roland Barthes tidak terlepas dari mitos sebagai bagian dari penelitiannya. Mitos adalah cerita suatu bangsa tentang dewa dan pahlawan zaman dahulu, mengandung penafsiran tentang asal-usul semesta alam, manusia, dan bangsa tersebut, mengandung arti mendalam yang diungkapkan dengan cara gaib (KEMENDIKBUD, 2016). Roland Barthes menyatakan bahwa mitos adalah semacam wicara, segalanya dapat menjadi mitos asal hal itu disampaikan lewat wacana (discourse). Mitos tidak didefinisikan oleh objek pesannya, tetapi oleh caranya menyatakan pesan (Barthes, 2010). Mitos merupakan produk kelas sosial yang mencapai dominasi melalui sejarah tertentu: maknanya, peredaran mitos tersebut mesti dengan membawa sejarahnya, namun operasinya sebagai mitos mengaburkan hal tersebut dengan menampilkannya sebagai sesuatu yang alami, dan bukan bersifat historis atau sosial tetapi lebih berdimensi sosial atau politik(Putra \& Yohana, 2015)

\section{METODE PENELITIAN}

Metode pada penelitian ini adalah kualitatif yakni penelitian yang menghasilkan data deskriptif, berupa kata-kata tertulis atau lisan dari orangorang dan perilaku yang diamati (Moleong, 2000). Dengan kata lain penelitian kualitatif adalah penelitian yang mengkaji data secara mendalam tentang semua kompleksitas yang ada dalam penelitian tanpa melalui prosedur statistik atau bentuk hitungan yang lainnya(Danim, 2002).

Jenis pendekatan yang dilakukan pada penelitian ini menggunakan analisis Semiotik. Semiotik adalah IImu tentang tanda-tanda. semiotik dapat didefinisikan sebagai ilmu yang mempelajari sederetan luas objek-objek, peristiwaperistiwa, seluruh kebudayaan sebagai tanda. Tanda didefinisikan sebagai sesuatu yang atas dasar konvensional sosial yang terbangun sebelumnya, dapat dianggap mewakili sesuatu yang lain(Sobur, 2016). Analisis semiotik pada penelitian ini menggunakan pendekatan semiotik Roland Barthes pada palantar nyangahatn manta' di upacara adat Nabo' Pantak Suku Dayak Kanayatn di Dusun Pakbuis Desa Banying, kecamatan Sengah Temila Kabupaten Landak Kalimantan Barat.

\section{PEMBAHASAN}

1. Baras Tujuh Biti' DENOTATIF

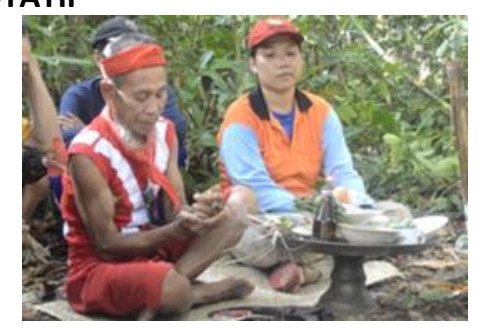

Sumber: dokumentasi pribadi, 2019

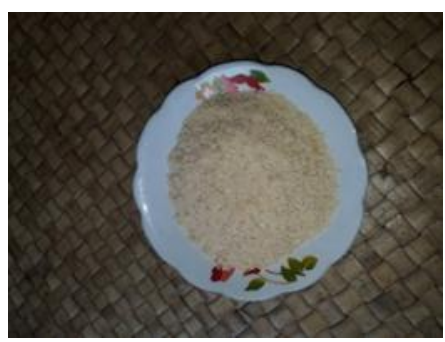


Sumber: dokumentasi pribadi, 2019

Baras tujuh biti' dalam bahasa Indonesia merupakan beras tujuh biji, beras berjumlah tujuh biji' tersebut dipilih, tidak boleh patah dan dalam keadaan utuh.

\section{KONOTATIF}

Baras tujuh biti'merupakan perwakilan dari tujuhbawakng (tempat keramat)(Bawakng Bajoa, Bawakng Bagantukng, Bawakng Sengekng, Bawakng Panampe, Bawakng Tungal, Bawakng Raya, Bawakng Basua')(panyangahatn, 03/04/2019). MITOS

Baras tujuh biti', meminta bekal kepada orang tua, dan bekal tersebut diharapkan jadi berkat dan rejeki serta kekayaan bagi yang menerima (panyangahatn, 03/04/2019).

\section{Roba Pelantar}

Roba Palantar, Baras Poe', Baras Sunguh, Talo', Ngkabakng, Mata Uang, Mata Perak, Pinang, Karake', Kapur, Gamer, Timako, Rokok, Tutu Ereh Topokng, Pampinangan

\section{DENOTATIF:}

1) Roba

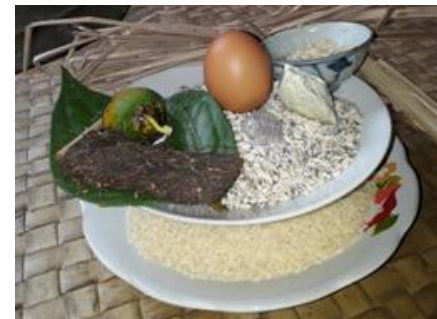

Sumber: dokumentasi pribadi, 2019

Roba adalah wadah yang terdiri dari beberapa peralatan nyangahatn yakni baras poe', baras sunguh, talo', ngkabakng, mata uang, mata perak, pinang, karake', kapur, gamer, timako, rokok, dan baras banyu.

\section{2) Roba Palantar}

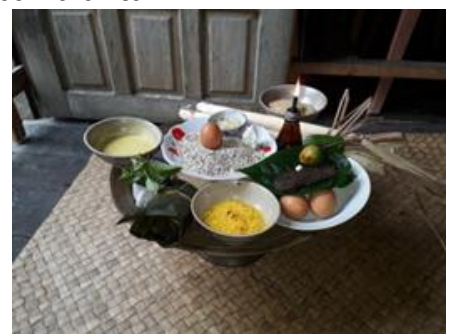

Sumber: dokumentasi pribadi, 2019

Roba palantar adalah pahar (wadah sejenis talam yang memiliki satu kaki) yang berisi perlengkapan nyangahatn, perlengkapan tersebut terdiri dari corong, daukng salasih, lamang, tumpi', baras banyu, kapur, pinang, karake', gamer, timako, rokok, baras poe', baras sunguh, talo', ngkabakng, mata uang, tapukng tawar, dan baras kuning.
3) Corong

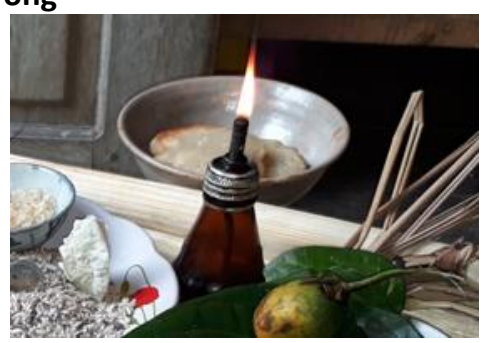

Sumber: dokumentasi pribadi, 2019

Corong dalam bahasa Indonesia adalah pelita yang berarti lampu yang berbahan bakar minyak.

4) Daukng Salasih

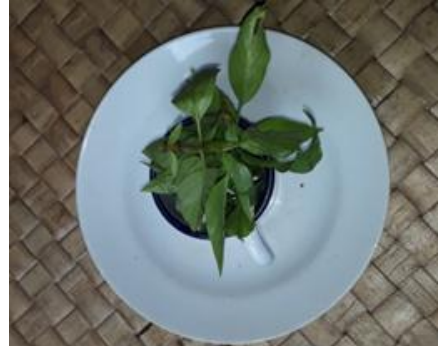

Sumber: dokumentasi pribadi, 2019

Daukng salasih dalam bahasa Indonesia daun selasih yaitu biasanya dicampur dalam minuman dingin, daunnya mengandung minyak asiri, digunakan dalam obat-obatan tradisional.

5) Lamang

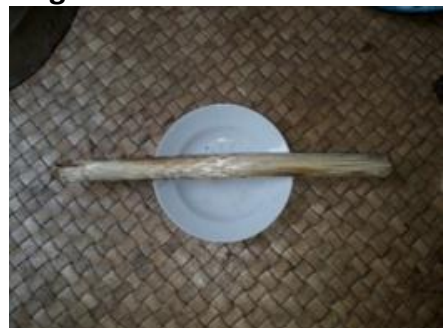

Sumber: dokumentasi pribadi, 2019

Lamang adalah ketan yang dimasak pada satu ruas batang bambu, Baras Poe' (Ketan) dimasak dicampur santan kelapa. Lamang merupakan makanan khas suku Dayak Kanayatn, pada setiap acara/upacara adat Poe' selalu digunakan

6) Tumpi'

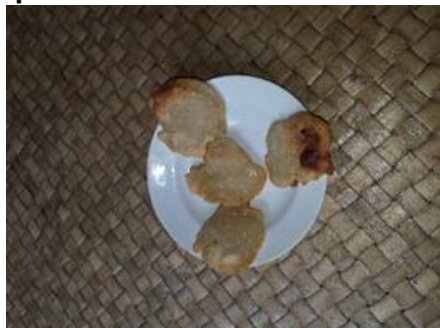

Sumber: dokumentasi pribadi, 2019 
Tumpi' adalah kue yang terbuat dari tepung beras, bentuk Tumpi'sama seperti cucur bisa dikatakan cucur Dayak, Tumpi' merupakan salah satu makanan khas suku Dayak Kanayatní, karena hampir disetiap acara/upacara adat pasti menyuguhkan Tumpi'.

\section{7) Baras Banyu}

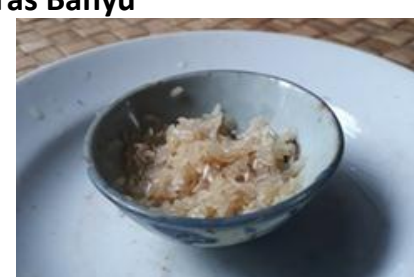

Sumber: dokumentasi pribadi, 2019

Baras banyu merupakan beras biasa yang dicampur dengan minyak kelapa.

8) Kapur

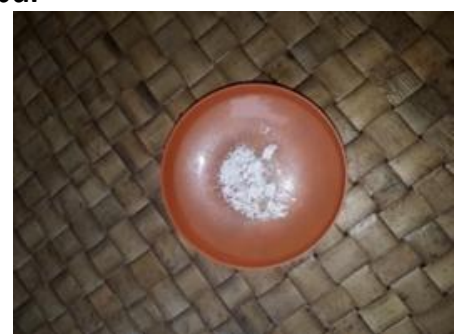

Sumber: dokumentasi pribadi, 2019

Kapur dalam bahasa Indonesia kapur yang merupakan kapur yang halus dan lembut untuk ramuan makan sirih. Kapur sirih ini berwana putih, basah dan liat, berasal dari cangkang tengkuyung sungai yang telah dibakar.

9) Pinang

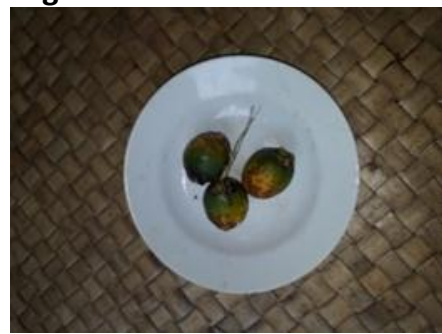

Sumber: dokumentasi pribadi, 2019

Pinangnama berbagai pohon dan buahnya yang termasuk kelompok palem, bentuk, jenis, dan kegunaannya beraneka ragam, tumbuhnya ada yang berumpun dan ada yang tunggal. Pinang yang digunakan pada upacara ini adalah buah pinangnya. 10) Karake'

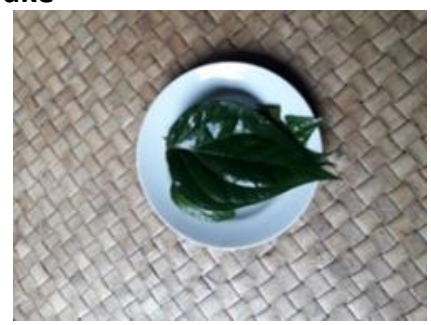

Sumber: dokumentasi pribadi, 2019

Karake' dalam bahasa Indonesia daun sirih merupakan tumbuhan merambat di pohon lain, daunnya berasa agak pedas, biasa dikunyah bersama dengan pinang, kapur, gambir sebagai makanan yang mencandu, penguat gigi, dan sebagainya. Untuk keperluan upacara jumlah daun tidak dibatasi, banyaknya daun sirih seperlunya saja.

11) Gamer

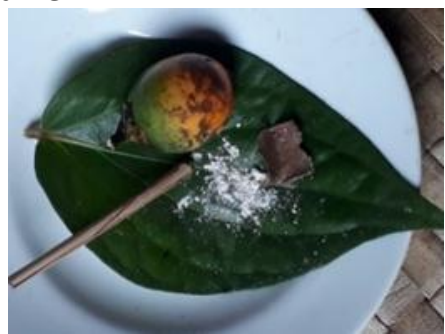

Sumber: dokumentasi pribadi, 2019

Gamer dalam bahasa Indonesia adalah gambir, merupakan tumbuhan membelit, berbatang keras, bertangkai pendek dengan daun berwarna hijau muda, pada ketiak daun terdapat bunga berbongkol bulat berwarna putih kecil-kecil, dipakai sebagai obat batuk dan bahan penyamak, ditanam dengan cara menyetek. Daun gambir dikeringkan untuk campuran makan sirih.

12) Timako

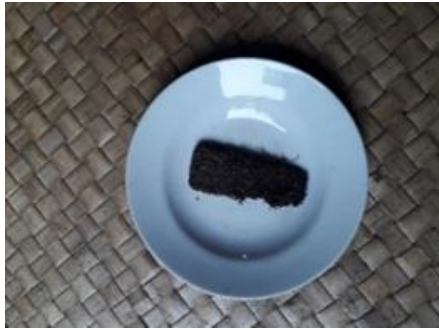

Sumber: dokumentasi pribadi, 2019

Timako dalam bahasa Indonesia adalah tembakau merupakan tumbuhan berdaun lebar, daunnya diracik halus dan dikeringkan untuk bahan rokok, cerutu, dan sebagainya. Tembakau yang digunakan pada upacara nabo' pantak biasanya tembakau jawa.

\section{3) Rokok Daukng}

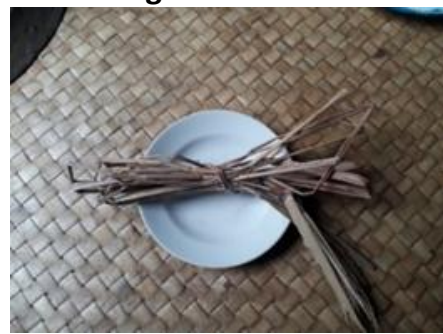

Sumber: dokumentasi pribadi, 2019

Rokok daukng dalam bahasa Indonesia rokok, merupakan gulungan tembakau (kira-kira sebesar kelingking) yang dibungkus (daun nipah, 
kertas). Rokok dari daun nipah tersebut tidak atau belum digabungkan/dicampur dengan tembakau.

\section{4) Baras Poe'}

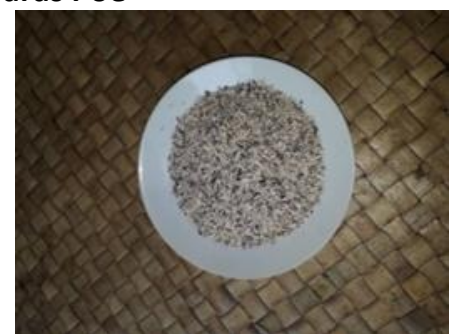

Sumber: dokumentasi pribadi, 2019

Baras poe' dalam bahasa Indonesia ketan, merupakan beras pulut, kalau dimasak biasanya menjadi lengket atau lekat; pulut. Beras pulut yang dibawa pada upacara tidak dimasak.

\section{5) Baras Sunguh}

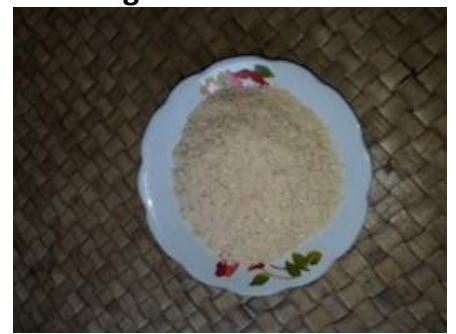

Sumber: dokumentasi pribadi, 2019

Baras sunguh dalam bahasa Indonesia beras, merupakan padi yang telah terkelupas kulitnya (yang menjadi nasi setelah ditanak). Beras yang dibawa pada upacara tidak dimasak.

\section{6) Talo'}

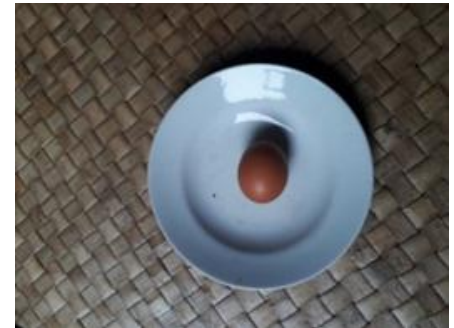

Sumber: dokumentasi pribadi, 2019

Talo' dalam bahasa Indonesia telur, merupakan benda bercangkang yang mengandung zat hidup bakal anak yang dihasilkan oleh unggas (ayam, itik, burung, dan sebagainya), biasanya dimakan (direbus, diceplok, didadar, dan sebagainya).Telur yang digunakan pada upacara adalah telur yang mentah dan masak.

\section{7) Ngkabakng}

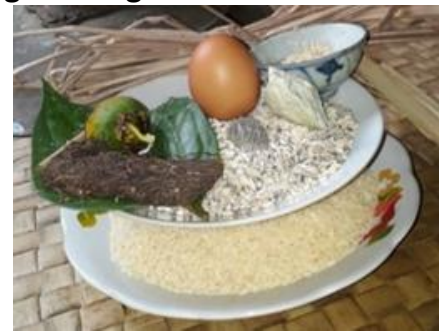

Sumber: dokumentasi pribadi, 2019
Ngkabakng dalam bahasa Indonesia tengkawang, merupakan pohon yang bijinya mengandung lemak nabati bernilai gizi sebagai minyak goreng, digunakan dalam industri makanan, sabun, obat-obatan, dan kosmetik. Bagian yang digunakan dari tengkawang pada upacara nabo' pantak adalah buah dari tengkawang, bisa juga minyak tengkawang yang sudah dibekukan (mengeras).

18) Mata Uang, Mata Perak

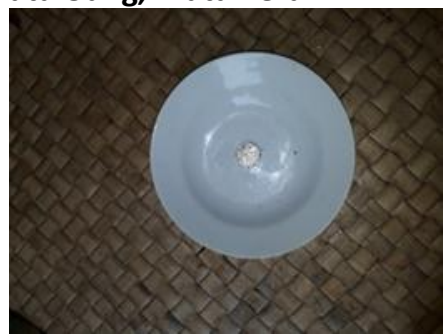

Sumber: dokumentasi pribadi, 2019

Mata uang, mata perak dalam bahasa Indonesia uang logam merupakan uang yang dibuat dari logam (seperti emas, perak). Uang perak yang digunakan sebagai mata pada upacara nabo' pantak tidak dibatasi berapa nilainya.

\section{KONOTATIF}

Roba Palantar, Baras Poe, Baras Sunguh sebagai persembahan untuk menyambut atau sebagai bentuk penerimaan terhadap orang yang kita undang, dengan kata lain bentuk suguhan kepada tamu yang diundang datang pada upacara tersebut (panyangahatn, 03/04/2019).

Corong yang bermakna penerang dalam perjalanan hidup seseorang, corong juga bermakna sebagai pemberi arah dalam hidup (panyangahatn, 03/04/2019).

Daukng salasih bermakna sebagai pembersih jiwa (jasmani dan rohani), supaya terhindar dari hal-hal jahat yang bersifat negatif (panyangahatn, 03/04/2019).

Makna lamang yaitu sebagai tongkat hidup/ penyangga hidup atau tali sengat (nafas kehidupan), dengan adanya penyangga hidup tersebut maka diyakini seseorang akan lebih tegar dalam menghadapi kesulitan dan kesusahan dalam kehidupannya. Lamang ini juga bermakna sebuah kebenaran, jika ada jalan yang salah maka akan dibenarkan, jika ada yang berbelok maka akan diluruskan, dengan demikian bahwa makna dari lamang adalah untuk hal kebaikan (panyangahatn, 03/04/2019).

Makna dari Tumpi' adalah petunjuk atau pedoman hidup, petunjuk atau pedoman hidup tersebut ke arah yang benar. Dengan adanya pedoman atau petunjuk hidup maka kehidupan akan terarah dan tertata. Tumpi' juga 
diumpamakan sebagai 'bintang penerang' yang berarti memberi petunjuk pada kehidupan agar bisa hidup dengan baik dan benar, selain itu, makna lain dari tumpi adalah tentang pemikiran yang bulat dan bersih (panyangahatn, 03/04/2019).

Baras banyu merupakan sumber kehidupan dan sumber keselamatan bagi umat manusia (panyangahatn, 03/04/2019).

Timako, Rokok, Karake, Pinang, Kapur, Gamer merupakan perlengkapan merokok dan nyirih, Timako, rokok, karake, pinang, kapur, gamer yang berarti tembakau, rokok (dari daun pandan), sirih, pinang, kapur sirih, dan gambir. Perlengkapan (alat peraga) tersebut berarti menawarkan atau berbagi dengan orang lain. Dalam pengertian tersebut memperlihatkan bahwa manusia adalah makhluk sosial, yang hidup dalam sebuah lingkungan yang saling memerlukan satu dengan yang lain (panyangahatn, 03/04/2019).

Talo' merupakan jantung, induk, pusat pada upacara, posisi telur harus berada di tengah-tengah palantar.Ngkabakng digunakan sebagai minyak dalam kehidupan sehari-hari (panyangahatn, 03/04/2019).

Mata Uang, Mata Perak adalah uang perak dan merupakan salah satu perlengkapan Nyangahatn. Maknanya adalah untuk pencerah dan penerang jalan, dan dijadikan sebagai bekal dan penunjuk dalam perjalanan hidup. Mata uang, mata perak harus selalu ada dalam palantar Nyangahatn, karena dengan adanya katep sebagai perlengkapan akan melancarkan rejeki bagi orang yang mengadakan upacara (panyangahatn, 03/04/2019). MITOS:

Roba Palantar, Baras Poe, Baras Sunguh, Talo', Ngkabakng, Mata Uang, Mata Perak, Pinang, Karake', Kapur, Gamer, Timako, Rokok, Tutu Ereh Topokng, Pampinangan merupakan sajian atau suguhan untuk membuka pembicaraan ketika ada tamu. Perlengkapan tersebut tidak boleh ada yang kurang, karena jika kurang akan menjadi badi (pengaruh buruk/negatif pada panyangahatn atau pelaksana upacara).

\section{Tapukng Tawar, Baras Kuning \\ DENOTATIF}

1) Tapukng Tawar

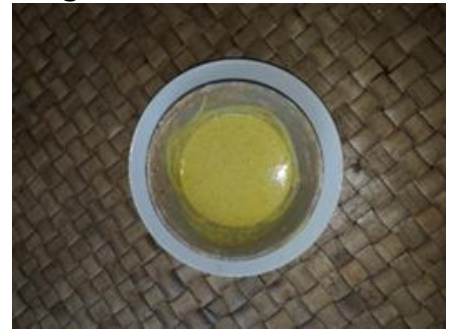

Sumber: dokumentasi pribadi, 2019
Tapukng tawar dalam bahasa Indonesia merupakan tepung beras biasa yang ditumbuk halus. Tepung tersebut dicampur air dan kunyit.

\section{2) Baras Kuning}

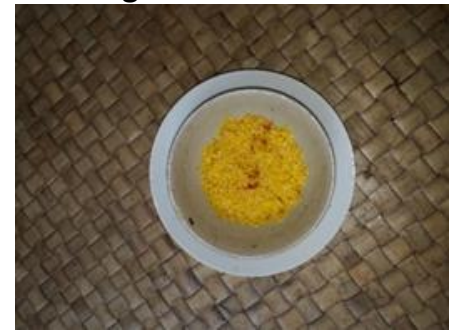

Sumber: dokumentasi pribadi, 2019

Baras kuning dalam bahasa Indonesia beras yang berwarna kuning. Beras tersebut dicampur dengan kunyit sehingga warna beras menjadi kuning.

\section{KONOTATIF}

Tapukng tawar dimaksudkan untuk mipis (membersihkan dan menjauhkan) segala bentuk hal yang bersifat kotor dan negatif, serta membersihkan dan menjauhkan dari segala marabahaya, (panyangahatn, 03/04/2019).

Baras kuning merupakan penolong manusia, dan menjadi perantara antara manusia dengan pencipta-Nya (panyangahatn, 03/04/2019).

\section{MITOS}

Tapukng tawar berfungsi nawar (supaya tidak berefek) atau menangkis segala bentuk kekuatan gaib atau mistis yang jahat.

Baras kuning berfungsi untuk menyelamatkan manusia.

\section{Seap Manok}

\section{DENOTATIF}

1) Seap manok

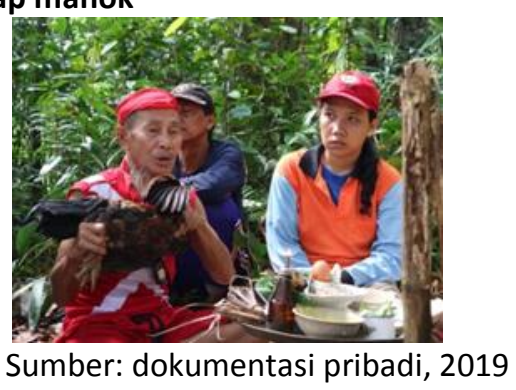

Seap manok dalam bahasa Indonesia merupakan sayap ayam, atau bagian tubuh dari ayam.

\section{KONOTATIF}

Seap manok digunakan untuk mipis (membersihkan), mengusir, menjauhkan segala 
bentuk hal negatif atau hal jahat yang akan. mengganggu manusia.

MITOS

Seap manok berfungsi membersihkan atau menjauhkan manusia dari hal negative atau hal buruk.

\section{SIMPULAN}

Berdasarkan hasil analisis pada palantar nyangahatn manta' upacara nabo' pantak tersebut maka ditemukan beberapa makna yakni 1) makna denotatif yang merupakan makna sebenarnya (realistis) yang sesuai gambar, 2) makna konotatif yang merupakan makna yang tidak tampak (tersembunyi) dari suatu apa yang tampak seperti gambar, dan 3) mitos dalam hal ini tidak ada hubungan berdasarkan kebenaran, tetapi hubungan berdasarkan penggunaan sehingga manusia menggunakan mitos berdasarkan kebutuhan.

\section{DAFTAR RUJUKAN}

Barthes, R. (2010). Membedah Mitos-Mitos Budaya Massa: Semiotika atau Sosiologi Tanda, Simbol, dan Representasi. Yogyakarta: Jalasutra.

Danim, S. (2002). Menjadi Peneliti Kualitatif. Bandung: Pustaka Setia.

KEMENDIKBUD, B. P. (2016, Agustus 24). KBBI Daring. Diambil kembali dari kbbi.kemdikbud.go.id:

https://kbbi.kemdikbud.go.id

Moleong, L. J. (2000). Metodologi penelitian Kualitatif. Bandung: PT Remaja Rosdakarya.

Pradopo, R. D. (2007). Pengkajian Puisi. Yogyakarta: Gadjah mada University Press.

Putra, W. W., \& Yohana, N. (2015). REPRESENTASI MAKNA SIMBOL RAGAM HIAS PADA RUMAH LONTIOK KABUPATEN KAMPAR RIAU(Analisis Semiotika Roland Barthes Mengenai Makna Simbol Rumah Lontiok di Desa Ranah Air Tiris Kabupaten Kampar). JOM, Vol. 2, No. 1, 1-15.

Sobur, A. (2016). Semiotika Komunikasi. Bandung: ROSDA.

Tinarbuko, S. (2009). Semiotika Komunikasi Visual (Edisi Revisi). Yogyakarta: Jalasutra.

Zoest, A. V. (1993). Semiotika: Tentang Tanda, Cara Kerjanya dan Apa yang Kita Lakukan Dengannya. Jakarta: Yayasan Sumber Agung. 